\title{
Activity Concentration in Cassava Tubers Grown In Ebedei Community, an Oil Producing Area of Delta State, Nigeria
}

\author{
K. Emumejaye \\ Department of Science Laboratory Technology, Delta State polytechnic, P.M.B 5, Ozoro, Nigeria
}

\begin{abstract}
Exploration and exploitation of crude oil and other human activities is known to technologically enhance the naturally occurring radionuclides in an area. This study is aimed to determine the activity concentration in cassava and estimate annual effective dose due to the consumption of these tubers by the populace. The activity concentration of potassium -40, Radium-226 and thorium 232 in six samples from the study area have been measured using a hyper pure germanium (HpGe) detector system. The radioactive concentration of the samples ranges from $370.62 \pm 15.3 \mathrm{~Bq} / \mathrm{kg}$ for potassium $-40,2.32 \pm 0.8-8.90 \pm 1.9 \mathrm{~Bq} / \mathrm{kg}$ for thorium-232 and $1.68 \pm 1.1-10.40 \pm 3.2 \mathrm{~Bq} / \mathrm{kg}$ for Radium-226. Estimated annual effective dose were also determined for each sample. Overall, the results are within the range of internationally recommended limits and no significant radiological hazard was found. The results of this study may be considered as the baseline levels of radioactivity in foodstuffs in these areas to check future activities.
\end{abstract}

Keywords: Annual effective dose, cassava, food crop, oil producing community, radioactivity

\section{Introduction}

Radiation is a natural part of the environment in which we live. All people receive exposure from naturally occurring radioactivity in soil, water, air and food. The greatest natural radiation exposure we receive comes from a radioactive radon gas. Radon $\left({ }^{222} \mathrm{Rn}\right)$ is emitted from uranium, a naturally occurring mineral in rocks and soil; thus, radon is present virtually everywhere in the air over the earth $[1,2]$. These radionuclides in the natural environment find their way into the human body majorly through food and water.

The most predominant naturally occurring radionuclides in foodstuffs is ${ }^{40} \mathrm{~K}$. Other contributions to the radio-nuclides in foods include deposited fallouts from fission and activation products released during nuclear accidents and constituents of weapons tests released after detonation [3]. It is a known fact that the status of the soil on which food crops are grown determines, to a great extent, the quality of foodstuffs produced [4]. Terrestrial radiation level varies from one geographical location to another depending upon the variation of radionuclide concentration in soil which is a function of the local geology $[5,6,7]$. As, plant uptake of radiation varies from species to species and also from place to place; hence the intake of different food products forms a secondary source of variability in radionuclides concentration ingestion. ${ }^{238} \mathrm{U},{ }^{232} \mathrm{Th}$ and ${ }^{40} \mathrm{~K}$ are three long-lived naturally occurring radionuclides present in the earth crust [8]. Naturally occurring radionuclides of ${ }^{228} \mathrm{Th}$ and ${ }^{238} \mathrm{U}$ have significant contributions in the ingestion dose and are present in the biotic system of plants, animals, soil, water and air. Distribution of radionuclides in different parts of the plant depends on the chemical characteristics and several parameters of the plants and soil [9].

Inhalation and ingestion are the main pathways through which natural radinuclides enter into the human body.
Tawalbeh et al [10], opined that ingested radionuclides could be concentrated in certain parts of the body. For example, Chemical uranium toxicity primarily affects the kidney, causing damage to the proximal tubule, while this metal has also been identified as a potential reproductive toxicant [11], ${ }^{232} \mathrm{Th}$ causes effect in lungs, liver and skeleton tissues and ${ }^{40} \mathrm{~K}$ in muscles. Depositions of large quantities of these radionuclides in particular organs will affect the health condition of the man such as weakening the immune system, induce various types of diseases, and finally increase in mortality rate [10].

A study by Akpabio and Ituen [12] attempted to measure the radioactivity level in roots grown in the coastal and hinterlands of the oil producing areas of Akwa Ibom state, Nigeria. The study reported the highest radioactivity level in yam and cassava samples. This may be due to oil activity happenings in the area.

Addo et al [13] investigated natural radioactivity ingestion from cassava grown and consumed by inhabitants around a cement factory in Ghana. The study revealed an annual effective dose of $1.23 \mathrm{mSv} / \mathrm{y}$ which is above the annual dose limit set by the International Convention for Radiological Protection (ICRP) for the general public, indicating a human health risk for the cassava consuming population in the study area. This study was therefore meant to assess radioactivity concentration in cassava in the oil producing community of Ebedei and make relevant recommendations to farmers, the cassava consuming populace and government agencies.

\section{Materials and methods}

\subsection{The Study Area}

The study area situated in two local government areas of Delta State namely: Ukwani local government area (Ebedei 


\section{International Journal of Science and Research (IJSR) \\ ISSN (Online): 2319-7064}

Index Copernicus Value (2015): 6.14 | Impact Factor (2014): 5.611

an oil producing community) and Aniocha South local government area (Ubulu Ukwu a non oil producing community). The people in the study area are predominantly farmers. They are well known for their farming prowess producing yam, cassava, melon, maize, tomatoes plantain and oil palm plantations. The study area lies within the Niger Delta sedimentary basin which is characterized by both Marine and mixed continental quaternary sediments that are composed of abandoned beach ridges and mangrove swamps [14]. The area experience wet and dry season which are typical seasons in Nigeria $[14,15,16]$.

\subsection{Samples Collection and Preparation}

Twelve samples of cassava tubers were collected from farms around a flow station at Ebedei, where there is constant gas flaring activity and cassava farms in Ubulu Ukwu community where there is no oil activity. Samples from Ubulu Ukwu served as control. At Ebedei two sampling locations around the flow station were selected and three samples were collected from each location. Six samples were also collected from two different sampling sites in Ubulu Ukwu community. All samples were sliced into bits, sun dried and then oven dried at $80^{\circ} \mathrm{c}$ until a constant weight is reached. Each sample was crushed and sieved using sieve mesh $(2 \mathrm{~mm})$ and kept in Marinelli container that has been washed, rinsed with dilute HCL and dried previously. The crushing and sieving was crucial for achieving homogeneous state of the sample [17]. The Marinelli containers and contents were hermetically sealed for at least 28 days to allow a sufficient time for ${ }^{238} \mathrm{U}$ and ${ }^{232} \mathrm{Th}$ to attain a state of secular equilibrium with their corresponding progenies before gamma spectroscopy [3].

\subsection{Determination of Radioactivity in Samples}

Gamma-ray spectrometer equipment is used. The gamma spectrometry system was equipped with a High purity germanium (HPGe) detector Model GR 2518-7500L (Canberra Industries Inc.) coupled to a computer based PCA-MR 8192 MCA mounted in a cylindrical $100 \mathrm{~mm}$ thick lead shield and an internal volume of approximately 88.50 L. The detector is cooled by liquid nitrogen from vertically dipstick cryostat dipped in $35 \mathrm{~L}$ liquid nitrogen Dewar. The detector has a relative efficiency of $25 \%$ to $\mathrm{NaI}$ detector, $1.8 \mathrm{keV}$ energy resolution at the energy peak of $1333 \mathrm{keV}$ of ${ }^{60} \mathrm{Co}$ isotope, and a peak-toCompton ratio of 55:1. The radionuclides were identified using gamma-ray spectrum analysis software, ORTEC MAESTRO-32.

The resolution of the HPGe detector made it possible to identify a large number of gamma-rays in the samples The photopeaks observed with regularity in the samples were identified as belonging to the radioactive decay series of ${ }^{238} \mathrm{U}$ and ${ }^{232} \mathrm{Th}$ and non-series radionuclides ${ }^{40} \mathrm{~K}$ and ${ }^{137} \mathrm{Cs}$. In some samples ${ }^{137} \mathrm{Cs}$ radionuclide appeared at low levels, or occurred at levels below the detectable limit (BDL). All the measurements were each carried out in a time of $36,000 \mathrm{~s}$ and same geometry was used to determine peak area of samples and references. The specific radio-activities of ${ }^{40} \mathrm{~K}$ and ${ }^{137} \mathrm{Cs}$ were determined directly by their gamma -lines of energies 1460.8 and $661.3 \mathrm{keV}$ respectively while that of ${ }^{226} \mathrm{Ra}$ and ${ }^{232} \mathrm{Th}$ were estimated by taking the mean of specific radioactivities obtained from the gamma -ray lines of energies 609.3 and $1120.3 \mathrm{keV}$ of ${ }^{214} \mathrm{Bi}$; for ${ }^{238} \mathrm{U}$ and $969.0 \mathrm{keV}$ of ${ }^{228} \mathrm{Ac}$ and $583.0 \mathrm{keV}$ of ${ }^{208} \mathrm{Tl}$ for ${ }^{232} \mathrm{Th}$ [3]. The gamma - ray background inside the shield was determined using an empty container the same measurement conditions. To ensure some level of accuracy of results the background was subtracted from the measured spectra of each sample before calculating the activity concentrations. The mass of cassava sample of used ranged between 75 and $200 \mathrm{~g}$ [18]. The activity concentrations were obtained using the expression [19]:

$$
C\left(B q k g^{-1}\right)=\frac{C_{n}}{\epsilon \rho_{\gamma} m_{s}}
$$

Where $\mathrm{C}$ is the activity concentration of the radionuclide in the sample, $C_{n}$ is the count rate under each photopeak due to each radionuclide, $\varepsilon$ is the detector efficiency of the specific gamma ray, $\mathrm{p}_{\gamma}$ is the absolute transition probability of the specific gamma ray and $\mathrm{m}_{\mathrm{s}}$ is the mass (dry weight in $\mathrm{kg}$ ) of the sample.

\section{Results and Discussion}

Table1 presents the results of activity concentrations in the samples analyzed. The activity concentration of ${ }^{40} \mathrm{~K}$ in cassava samples are relatively high and compared very well with results obtained elsewhere within the region. The highest value of $370.62 \pm 15.3 \mathrm{~Bq} / \mathrm{kg}$ and $128.87 \pm 8.3 \mathrm{~Bq} / \mathrm{kg}$ in cassava samples from Ebedeil and Ubulu ukwul respectively were registered for ${ }^{40} \mathrm{~K}$. The high concentration of ${ }^{40} \mathrm{~K}$ in cassava may be due to the use of fertilizers by farmers in the area. Also it has been reported that the major bedrocks in the study area are known to accumulate naturally occurring radioactive material may probably be responsible for the high activity of ${ }^{40} \mathrm{~K}$ in samples both at the study area and the control area (Ubulu Ukwu) where there are no oil activities [20]. The activity concentration for 


\section{International Journal of Science and Research (IJSR) \\ ISSN (Online): 2319-7064}

Index Copernicus Value (2015): 6.14 | Impact Factor (2014): 5.611

Table 1: Results of activity concentration in cassava samples

\begin{tabular}{|c|c|c|c|c|c|}
\hline \multicolumn{5}{|c|}{ Activity concentration } & \multirow{2}{*}{$\begin{array}{c}\text { Annual Effective } \\
\text { Dose }(\mathrm{mSv} / \mathrm{y})\end{array}$} \\
\hline Sample location & Sample code & ${ }^{40} \mathrm{~K}(\mathrm{~Bq} / \mathrm{kg})$ & ${ }^{232} \mathrm{Th}(\mathrm{Bq} / \mathrm{kg})$ & ${ }^{226} \mathrm{Ra}(\mathrm{Bq} / \mathrm{kg})$ & \\
\hline \multirow[t]{3}{*}{ Ebedei 1} & E1 & $324.01 \pm 18.3$ & $5.56 \pm 2.3$ & $9.01 \pm 3.0$ & 0.53 \\
\hline & $\mathrm{E} 2$ & $201.34 \pm 14.2$ & $12.84 \pm 3.5$ & $8.34 \pm 2.5$ & 0.44 \\
\hline & E3 & $128.87 \pm 8.3$ & $16.78 \pm 3.1$ & $10.40 \pm 3.2$ & 0.47 \\
\hline \multirow[t]{3}{*}{ Ebedei 2} & E4 & $192.66 \pm 10.4$ & $6.12 \pm 2.4$ & $7.56 \pm 2.2$ & 0.39 \\
\hline & E5 & $180.45 \pm 5.2$ & $18.03 \pm 4.2$ & $6.02 \pm 2.1$ & 0.37 \\
\hline & E6 & $243.54 \pm 7.0$ & $8.90 \pm 1.9$ & $9.23 \pm 2.7$ & 0.49 \\
\hline \multirow{3}{*}{$\begin{array}{l}\text { Ubulu Ukwu1 } \\
\text { (Control site) }\end{array}$} & U1 & $345.60 \pm 9.7$ & $4.62 \pm 2.0$ & $2.46 \pm 1.5$ & 0.33 \\
\hline & U2 & $300.23 \pm 12.5$ & $6.24 \pm 3.2$ & $4.71 \pm 2.1$ & 0.38 \\
\hline & U3 & $370.62 \pm 15.3$ & $5.21 \pm 2.2$ & $3.21 \pm 1.3$ & 0.37 \\
\hline \multirow{3}{*}{$\begin{array}{l}\text { Ubulu Ukwu2 } \\
\text { (Contro site) }\end{array}$} & U4 & $256.88 \pm 17.5$ & $3.54 \pm 1.9$ & BDL & 0.19 \\
\hline & U5 & $290.01 \pm 12.2$ & $2.32 \pm 0.8$ & $1.68 \pm 1.1$ & 0.26 \\
\hline & U6 & $351.42 \pm 13.9$ & $4.12 \pm 2.1$ & $1.98 \pm 1.3$ & 0.32 \\
\hline \multicolumn{2}{|l|}{ Average } & $211.81 \pm 10.6$ & $11.37 \pm 2.9$ & $8.43 \pm 2.6$ & 0.45 \\
\hline \multicolumn{2}{|l|}{ Average (control) } & $319.13 \pm 13.5$ & $4.34 \pm 2.0$ & $2.34 \pm 1.2$ & 0.31 \\
\hline
\end{tabular}

$\mathrm{BDL}=$ below detection limit

${ }^{232} \mathrm{Th}$ are slightly higher than that from ${ }^{226} \mathrm{Ra}$. The cassava tubers are usually big and long penetrating into the soil with increased ability to absorb more radionuclides [3]. ${ }^{226} \mathrm{Ra}$ activity ranged from $1.68 \pm 1.1-10.40 \pm 3.2 \mathrm{~Bq} / \mathrm{kg}$ while ${ }^{232} \mathrm{Th}$ values were within the range of $2.32 \pm 0.8-8.90 \pm 1.9$ $\mathrm{Bq} / \mathrm{kg}$. The activity levels detected, although relatively high, are within the internationally accepted range and comparable with those reported in other parts of Nigeria [18].

\section{Annual Effective dose from ingestion of cassava samples}

The effective dose $E$ ( $\mathrm{Sv}$ per year) due to intake of a radionuclide with the ingested material is calculated using the following expression [21]:

$$
A E D=A \Sigma C_{i} D C F_{i}
$$

Where $A(\mathrm{~kg} / \mathrm{yr})$ is mean annual consumption of foodstuff; $C_{i}$ $(\mathrm{Bq} / \mathrm{kg})$ is activity concentration of radionuclide $i$ in the ingested material; and $D C F_{i}(\mathrm{~Sv} / \mathrm{Bq})$ is dose coefficients for radionuclide $i$. In Summing over $i$ which should include all the radionuclides present in the ingested material, but only, ${ }^{232} \mathrm{Th},{ }^{226} \mathrm{Ra}$, and ${ }^{40} \mathrm{~K}$, were considered, and the corresponding dose coefficients are 2.8 E-07, 0.23 E-07 and 0.06 E-07 $\mathrm{Sv} / \mathrm{Bq}$, respectively [22]. The mean consumption of cassava per capita is $115.46 \mathrm{kgy}^{-1}$ in Nigeria [23]. Using these conversion factors in equation (2), the effective doses due to ingestion were estimated in the various samples. The result of this computation is in column five of Table 1 . The average annual effective dose from ingestion of cassava was 0.45 and $0.31 \mathrm{mSv} / \mathrm{y}$ for the study area and control site respectively. The annual effective dose values registered in the study area were higher than those of the control site; this may probably be due to the activities of petroleum exploration in the area [12]. These values are below the annual dose limit of $1 \mathrm{mSv} / \mathrm{y}$ for the general public, hence may not pose serious health hazards on the consumer.

\section{Conclusion and Recommendations}

This study reveals high radioactivity concentration in the study area and control, in all samples and the activity was primarily from ${ }^{40} \mathrm{~K}$. The values of ${ }^{232} \mathrm{Th}$ were slightly higher than that ${ }^{226} \mathrm{Ra}$ in all studied samples and were comparable with values observed in Jos- Plateau. Also the estimated annual effective dose from the ingestion of cassava were below permissible limits and seen not to pose any serious internal health problem due to ingestion by individuals in the study area. However, a community based sensitization of the people on the issues of environmental contamination and its health implication is recommended for relevant regulatory agencies.

\section{References}

[1] Sahar A. A, Afaf A. A and Azhar M. H Physicochemical properties and radioactivity assessment of Iraqi dates International Journal of Advanced Research (2014), 2(10), 978-980

[2] UNSCEAR (2000) Sources and effects of ionizing radiation in Report to the General assembly with scientific annexes, New York, United Nations.

[3] Tchokossa, P, Olomo, J.B, Balogun, F. A and Adesanmi,C.A (2013). Assessment of Radioactivity Contents of Food in the Oil and Gas Producing Areas in Delta State, Nigeria. International Journal of Science and Technology, 3(4):245-250

[4] Jibiri, N. N. (2001), Assessment of Health Risk Associated with Terrestrial Gamma Radiation Dose Rate Levels in Nigeria. Environment International, 27(1): 21 26.

[5] Farai, I. P. and Jibiri, N. N. (2000), Baseline Studies of Terres-trial Outdoor Gamma Dose Rate Levels in Nigeria. Ra-diation Protection Dosimetry, 88(3) :247254.

[6] Jibiri, N. N. and Bankole, O. S. (2006), Soil radioactivity and radiation absorbed dose rates at roadsides in high-traffic density areas in Ibadan metropolis, southwestern Nigeria, Radiation Protection Dosimetry, 18(4):153-158

[7] Bikit, I., J. Slivka, Lj. Conkic, Lj. Krmar, M. Veskovic, N.Zikic-Todovovic, E. Varga, S.Curcic and M. Mrdja(2005). Radioactivity of the soil in Vojvodina (northern province of Sebia and Montenegro). $J$. Environ. Radioact., $78: 11-19$

[8] Saleh, I. H., Hafe, A.F., Alanary, N.H., Motaoveh, H. A. and Naim, M.A. (2007), Radiological Study of Soils, Foodstuff and Fertilizers in the Alexandria

\section{Volume 4 Issue 11, November 2015}




\section{International Journal of Science and Research (IJSR) \\ ISSN (Online): 2319-7064}

Index Copernicus Value (2015): 6.14 | Impact Factor (2014): 5.611

region,Egypt, Turkey Journal of Environmental Science, 31, pp 9-17.

[9] Shanthi, G., Maniyan, C. G., Allan, G., Raj, G. and Kumaran, J. T. T (2009). Radioactivity in food crops from high background radiation area in southwest India, Current Science, 97(9), : 1331-1335

[10] Tawalbeh, A. A., Samat, S. B., Yasir,M. S. and Omar, M. (2012), Radiological impact of drinks intakes of naturally occurring radionuclides on adults of central zone of Malaysia, Malaysian Journal of Analytical Sciences, 16(2), pp187-193.

[11]Linares, V., Bellés, M., Albina, M. L., Sirvent, ., J. J., Sánchez, D. J. and Domingo, J. L. (2006), Assessment of the pro-oxidant activity of uranium in kidney and testis of rats, Toxicology Letters, $167: 152-161$.

[12] Akpabio,G.T and Ituen,E.E (2006) Comparative effect of radioactive radiation on roots in coastal and hinterland locations in Akwa Ibom State, Nigeria. Nigerian Journal of physics, 18(1)

[13] Addo M.A, Darko E.O, Gordon C, Nyarko B.J.B (2013) A preliminary study of natural radioactivity ingestion from cassava grown and consumed by inhabitants around a cement production facility in the Volta region, Ghana. International Journal of Environmental Sciences, 3(6):2312-2323

[14] Anoliefo. G.O (1991), Forcados Blend crude oil effects in Respiratory mechanism, mineral element composition and growth of citrulus vulgaris school unpublished doctoral thesis, university of Benin.

[15]Eteng - Inya A., (1997). The Nigerian State, Oil Exploration and Community Interest: Issues and Perspectives. University of Port Harcourt, Nigeria conf paper

[16]Etu - Efeotor J.O (1998). Hydrochemical analysis of surface and ground waters of Gwagwalada area of central Nigeria. Globa $J$

[17] Al-Hamidawi, A.A.A (2015) NORM in Instant Noodles (Indomie) Sold in Iraq. J Environ Anal Chem , 2:4

[18] Jibiri N.N and Agomuo J.C (2007) Trace elements and radioactivity measurements in some terrestrial food crops in Jos-plateau, north central, Nigeria, Radioprotection, 42 (1): $29-42$

[19] Akinloye M.K., Olomo J.B. (2000) The measurement of the natural radioactivity in some tubers cultivated in farmlands within the Obafemi Awolowo University IleIfe, Nigeria, Nig. J. Phys. 12: 60-63.

[20]Baeza, A., Paniagua, J., Rufo, M., Guillen, J. and Sterling, A., (2001) "Seasonal variations inradionuclide transfer in a Mediterranean grazing-land ecosystem". Journal of Environmental Radioactivity 55:283-302.

[21] Cunha, I.I.L., Rodrigues Jr., O. and Figueira, R.C.L. (1995), Assessment of doses to the Brazilian population from radioactive marine food, In: Proceedings of an international symposium on environmental impact of radioactive releases". IAEA, Vienna, 8-12 May 1995: 695-697.

[22] Shanthia, G., Kumaranb, T. T., Rajc, G. A. G., Maniyand, C. G. (2012), Natural radionuclides in the South Indian foods and their annual dose, available at http://npcil.nic.in/pdf/Article_14mar2012_01.pdf accessed on August 12, 2013.
[23] Maziya-Dixon B., Akinyele I.O., Oguntona E.B., Sanusi R.A., Harris E. (2004) Nigeria food consumption and nutrition survey 2001-2003 (Summary), Publication of the International Institute of Tropical Agriculture (IITA), Ibadan, Nigeria, Nigeria Food Survey 1: 1-75. 